\title{
ENTRE O VERBAL E O NÃO VERBAL: NATUREZA E EROTISMO NA POESIA DE LUIZ BACELLAR E NA FOTOGRAFIA DE NORMANDY LITAIFF.
}

\author{
Lucas Freitas Cabral Neto ${ }^{1}$ \\ MSc. Adriana Aguiar ${ }^{2}$
}

RESUMO: Os termos, sexo, amor e erotismo, apesar de estarem intrinsicamente relacionados, são conceitualmente distintos entre si. Partindo das definições de erotismo estabelecidas por Octavio Paz e Bataille, este artigo tem como objetivo uma análise intersemiótica da poesia de Luiz Bacellar, e das fotografias de Normandy Litaiff. Com a análise das obras de Litaiff e Bacellar, percebemos que, apesar de serem distintas, elas abordam o erótico com uma nova perspectiva: o ícone estático, tanto das frutas amazônicas e da natureza morta, passa a receber um novo signo erotizado.

PALAVRAS-CHAVE: Poesia; Fotografia; Erotismo; Bacellar; Litaiff.

\section{Poesia, fotografia e natureza: relações intersemióticas}

A poesia enquanto arte, pode ser estudada das mais diversas formas possíveis, dentre as quais, pode-se fazer uma relação intersemiótica com a fotografia, através de imagens, exprimindo por meio de ilustrações aquilo que o autor possa ter imaginado para a sua poesia. Partindo desta premissa a Semiótica, sendo uma ciência relativamente nova busca mostrar como podemos desvendar o mundo através de análise entre diversos signos, desde os mais simples, como bilhetes ou recados deixados na porta da geladeira, bem como textos acadêmicos e científicos. Mediante as considerações feitas anteriormente, interpela-se: como se dá a representação erótica dos signos da natureza na poesia de Bacellar e na fotografia de Litaiff?

O presente artigo visa mostrar a obra de Luiz Bacellar, Sol de feira, na qual o autor explora signos da natureza amazônica, dando a eles uma carga de lirismo e erotismo. Bacellar utiliza das frutas amazônicas, dando-lhes novos significados, os signos eróticos, em que a natureza deixa de ser um ícone estático e passa a ser a protagonista de sua poesia erotizada.

As fotografias de Litaiff também exploram de forma erótica os signos da natureza, traduzindo-a em signos culturalmente eróticos. Não há somente a natureza morta, mas sim a natureza erotizada, assumindo assim um novo ícone.

\footnotetext{
1 Aluno do Curso de Especialização em Metodologia do Ensino de Língua Portuguesa e suas Literaturas da Universidade do Estado do Amazonas - UEA. E-mail: lucasneto77@ @otmail.com

2 Mestra em Letras - Estudos Literários / UFAM. Professora do Curso de Especialização em Metodologia do Ensino de Língua Portuguesa e suas Literaturas da Universidade do Estado do Amazonas - UEA. E-mail: adrinaguiarodrigues@gmail.com
} 
Dentre os vários tipos de mídia que aliam a beleza estética proporcionada pela arte à informação e documentação de temas sociais, a fotografia surge como uma forma de testemunha da sociedade, registrando a expressão cultural dos povos a partir de meados do século XIX, onde o registro de paisagens rurais e urbanas nos permitiu conhecer a evolução da sociedade moderna, e também tomar conhecimento das mudanças ocorridas no meio ambiente após a corrida tecnológica do século XX, a degradação das espécies naturais em favor do progresso urbano e industrial. (KOSSOY, 1989).

Suassuna (1975), parafraseando Hegel, explicita que a beleza natural, do mundo ao redor, foi apenas criada, e apreciada por nós, seres racionais; já a beleza artística, além de criada pelo absoluto, é recriada pelo espírito humano. Portanto, a fotografia artística alia estes dois tipos de beleza em uma união estética que cria uma perspectiva sobre o mundo ao redor, que é pertencente ao fotógrafo e revelada ao mundo. A fotografia, através de seus elementos constitutivos, emprega a vida ao redor do fotógrafo como agente principal de interesse e atenção através de uma representação estética resultante do processo de criação/construção do fotógrafo, que pode dramatizar ou valorizar esteticamente seus cenários (KOSSOY, 2002), de acordo com sua inspiração e trabalho artístico, revelando-se como uma grande estimulação natural à sensibilidade humana através da imagem estática construída de forma a captar o olhar de forma contempladora.

A poesia é a arte vivente do poeta, aquela que perpassa todo o caminho imaginativo do escritor. Logo, poderá também ser analisada com a fotografia, podendo através do ícone da imagem, vislumbrar o que o autor imaginou para a sua obra, tendo em vista que, pode-se fazer uma análise intersemiótica entre a poesia e a fotografia.

Lucia Santaella, em Leitura de imagens, defende que fotografar é "um ato de escolha, fruto de uma atenção seletiva" (2012, p. 76). Assim sendo, quando o fotógrafo projeta sua lente em uma determinada imagem, ele está intensificando seu devotamento rigoroso ao quadro em que ele quer perpetuar. A natureza sempre foi um tema bastante presente na literatura e nas artes em geral, pois desde os primeiros textos da literatura brasileira a natureza já era um tema presente, como na Carta de Pero Vaz de Caminha.

\footnotetext{
Alguns traziam uns ouriços verdes, de árvores, que, na cor, queriam parecer de castanheiros, embora mais pequenos. E eram cheios duns grãos vermelhos pequenos, que, esmagando-os entre os dedos, faziam tintura muito vermelha, de que eles andavam tintos. E quanto mais se molhavam, tanto mais vermelhos ficavam (CAMINHA, 1999, p.6)
} 
Outros autores também retratam a natureza em poesia, dentre eles temos Machado de Assis, que em sua poesia intitulada "As Rosas" retrata o amor em forma de flor

Rosas que desabrochais,

Como os primeiros amores

Aos suaves resplendores

Matinais (DE ASSIS, 1994, p. 37)

Há também grandes escritores amazonenses que retratam a natureza local em forma de poesia. Anibal Beça, em "Quantum” iguala o amor que sente por sua amada, com a beleza da natureza da região amazônica:

Teu corpo é a minha natureza onde celebro as horas

em silêncio

tateando o rumor de arrepios.

Minhas mãos galhos ritmados

ventos da ventura

em tua pele

embalando folhas

na ponta dos dedos

Da umidade dos poros

pequenas vertentes afloram

lagos lacrimados de sal

que a minha língua morde.

Sob a fronde do arbusto

a sombra do desejo se abriga

fruta rubra oferecida

paisagem

colhida e recolhida

estremeço por inteiro

e o céu me interroga:

“Quantos grãos da clepsidra?” (BEÇA, 2013, p.47)

Outro autor amazonense que exalta a natureza em poesia é Celdo Braga, em “Amazonas - Paixão por Você”, o autor retrata seu imenso amor pelo Amazonas, a fauna e a flora de forma sútil e poética

Nas águas da esperança nasce um rio novo no vôo da garça branca um novo amanhecer e o canoeiro vai remando a lida, barco de sonhos que carrega a vida.

Amazonas - paixão por você.

No coração da mata, tambores de lendas;

na mistura das raças pele não tem cor. 
E o homem livre, bandeira do norte, com alegria vai tocando a sorte, cumprindo a sina do semeador. No bumba do meu boi, a saga da história; aqui é meu lugar, aqui hei de morrer. Terra-brinquedo, sonho de menino, quero entregar a ti o meu destino. Amazonas - paixão por você. (BRAGA, 2010, p.50)

A correlação do ser humano com a natureza é cultuada a fim de criar um campo semântico de termos à nossa fauna e flora formando um paroxismo entre o mundo etéreo e o real. Partindo dessa relação dalística, o homem enquanto ser racional busca poetizar a natureza tecendo um mundo utópico adicionando características incomuns a itens que compõem nosso planeta.

A natureza é muito mais do que um mero tema, é muito mais uma categoria do pensamento fotográfico. E como categoria, aludir à natureza tanto é capaz de nos fazer entender o mundo quanto entender a própria fotografia. Pois longe de ser natural, a natureza é o espaço privilegiado de construção do imaginário fotográfico, como intuía perfeitamente Man Ray, ao dizer que não fotografa a natureza, mas sua fantasia: "É maravilhoso explorar os aspectos que sua retina não pode registrar" (1975 apud SCGWARTZ, 1977, p. 323)

Por outro lado, o que a fotografia é capaz de captar está intrinsecamente ligado a sua própria natureza, seus princípios, sua essência - ou seja, ao conjunto de elementos que a fazem ser o que ela é em seu aspecto material, em sua materialidade corpórea, mas também na sua dimensão metafísica - no que ela revela, às vezes não por mostrar, mas por escamotear. A fotografia materializa sua natureza ao se colocar em operação. A fotografia está ligada diretamente à natureza, ao real, ao índice e consequentemente incluída numa questão de verossimilhança com o real.

\section{ENTRE O EROTISMO, O AMOR E O SEXO}

É comum, no cotidiano, estabelecer relação sinonímia entre amor, sexo e erotismo, pois os três sustentam um pilar muito importante na psique humana: a de que através de um dos três, podemos contemplar um bem supremo com outra pessoa, ou seja, podemos atingir um sentimento mútuo de satisfação, uma relação recíproca entre as duas partes. Segundo o escritor Octavio Paz, em A dupla chama: amor e erotismo, "antes de tudo, o erotismo é exclusivamente humano: é sexualidade socializada e transfigurada pela imaginação e vontade dos homens" 
(1994, p. 16). O erotismo parte primeiramente da imaginação que se tem do outro, buscando assim, algo que por ventura se possa almejar, no caso, o sexo.

Paz inter-relaciona que a "poesia e erotismo nascem dos sentidos, mas não terminam neles. Ao se soltarem, inventam configurações imaginárias - poemas e cerimônias" (1994, p.14). Tudo começa a partir da imaginação humana onde, através dela, cada indivíduo irá atribuir seu sentindo de linguagem de acordo com o que deseja com seu parceiro.

Já a definição de amor, conforme Paz, faz um contraponto com o erotismo, pois no primeiro caso trata-se de um grande apreço por outra pessoa, o qual transcende o desejo carnal; já o erotismo é a percepção que a pessoa almeja pela outra, a qual cada indivíduo busca de forma singular o seu desejo, de forma mais lasciva:

O amor é uma atração por uma única pessoa: por um corpo e uma alma. O amor é escolha; o erotismo, aceitação. Sem erotismo - sem forma visível que entra pelos sentidos - não há amor, mas este atravessa o corpo desejado e procura a alma no corpo e, na alma, o corpo. A pessoa inteira (1994, p.34).

Para Georges Bataille, em O Erotismo, a definição de amor consiste em uma busca incansável de um sentimento de perda do outro amado. Logo o desejo de amar acaba transcendendo até mesmo o sentimento da morte, pois não se sabe quando poderá perdê-lo.

Essencialmente, o amor eleva o gosto de um ser por um outro a esse grau de tensão em que a privação eventual da posse do outro - ou a perda de seu amor — não é sentida menos duramente que uma ameaça de morte. Assim, ele tem por fundamento o desejo de viver na angústia, em presença de um objeto de valor tão grande que aquele que teme perdê-lo sente o coração falhar. A febre sensual não é o desejo de morrer. Da mesma forma, o amor não é o desejo de perder, mas o de viver no medo de sua perda possível, o ser amado mantendo o amante à beira do esgotamento: a este preço, somente, podemos sentir diante do ser amado a violência do encantamento. (1987, p.156)

Na visão de Paz, o sexo não obedece à uma ordem ou a um poder estabelecido, tendo em vista que ele não segue regra alguma, tudo pode acontecer entre as pessoas que estão fazendo o ato em si. Sabe-se também que o ato sexual se iniciou desde a criação, além de ser fonte primordial (1994, p. 15). O animal segue seu instinto para poder procriar e faz uso do sexo para tal fim; no entanto, o homem necessita do sexo não somente para a procriação, mas para poder também (e sobretudo) sentir prazer. 
O sexo é subversivo: ignora as classes e hierarquias, as artes e as ciências, o dia e a noite; dorme e só acorda para fornicar e voltar a dormir. Nova diferença com o mundo animal: a espécie humana padece de uma insaciável sede sexual e não conhece, como os outros animais, períodos de excitação e períodos de repouso, ou dito de outra forma: o homem é o único ser vivo que não dispõe de uma regulação fisiológica e automática de sua sexualidade. (1994, p.17)

$\mathrm{Na}$ tríade sexo, amor e erotismo, percebe-se que o pensamento humano funciona de forma muito subjetiva, pois cada pessoa idealizará o par perfeito. Isso vem desde a idealização do ser inalcançável, a quem almejamos e em quem depositamos todo nosso afeto (não importando aqui para qual fundamento final). Fazendo uma analogia muito interessante, Paz compara a tríade a uma planta "o sexo é a raiz, o erotismo é o talo, e o amor, a flor. E o fruto? Os frutos do amor são intangíveis. Este é um de seus enigmas" (1994, p. 37). Percebemos que a natureza está intercalada de certa forma com emoções humanas, como o erotismo, o qual pode ter entendimento através do olhar de autores, como Bacellar e Litaiff, que deram uma nova perspectiva as frutas amazônicas e aos pedaços de madeira e colmeias de formigas.

\section{NATUREZA E EROTISMO}

A natureza, enquanto símbolo significativo, acaba por representar não somente a fauna e a flora de uma região, mas também uma busca de um mundo perfeito o qual o homem busca incessantemente, mediante a poesia, uma utopia bucólica. Por conta dessa busca infindável e pela natureza ser esta insígnia tão eloquente, a professora Angélica Soares, no artigo "Por uma recriação ecológica do erotismo: flashes da poesia brasileira e portuguesa contemporâneas de autoria feminina", destaca que

\footnotetext{
Uma recepção ecológica e comparada da poesia erótica brasileira e portuguesa contemporâneas de autoria feminina permite-nos detectar que, ao serem transmitidas imagens de interação entre o corpo e a Natureza, apontam-se modos de fortalecimento que, como se sabe, é condição básica para que haja transformações positivas no socius. Sendo assim, na leitura dos poemas somos conduzidos a pensar como Félix Guattari (1989) no inter-relacionamento dos registros ecológicos ambiental, social e subjetivo; o que, em sua ecosofia, é necessário para alcançarmos um equilíbrio ecológico. (2009, p. 82)
}

Ora, a natureza como objeto estético deixa de ser apenas fauna e flora e passa a ser a grande protagonista, o agente transformador humano. Em todo o seu artigo, Soares apresenta, a partir da visão feminina, como a natureza pode ser trabalhada de forma erótica, de modo que a 
mulher, enquanto agente ativo de seu próprio prazer, pode ser analisado com a natureza em questão. Um exemplo de autora "cuja obra sempre se voltou para a liberação erótico-social da mulher" (SOARES, 2009, p. 84).

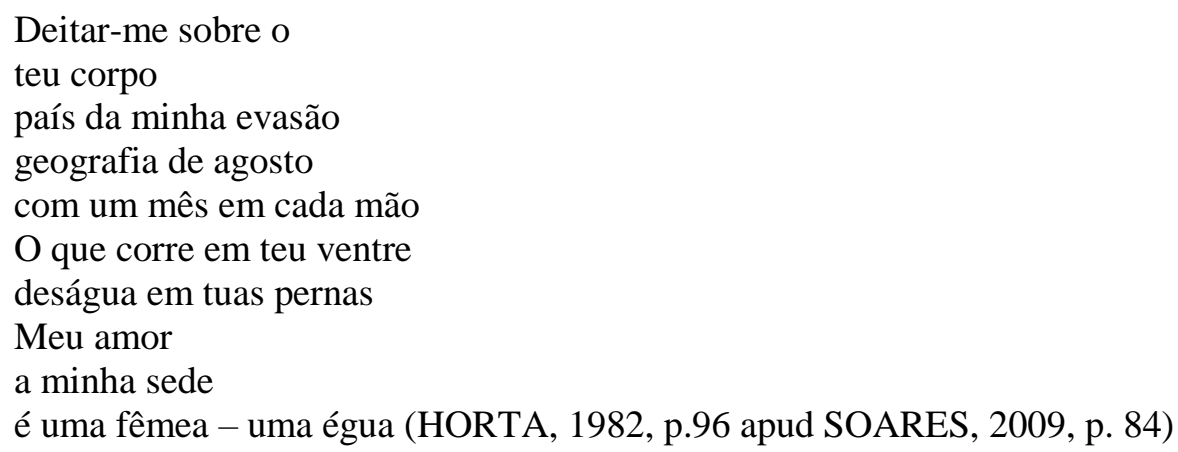

A mulher, nesse caso, é a protagonista da cena amorosa, ela deixa de ser aquela que somente se deita na cama e recebia as ordens de seu parceiro sexual; a mulher acaba de se transformar no agente que busca seu próprio prazer. A natureza aqui, é representada de forma selvagem, elencando o desejo animal que ela sente para obter seu regozijo.

Outra poetisa citada por Soares, é a pernambucana Lourdes Sarmento, a qual “(...) no poema "A Fera" vai buscar, na simbologia animal, um modo de identificar-se a mulher pela sua impetuosidade, quando estimulada pelas sensações eróticas” $(2009$, p. 89)

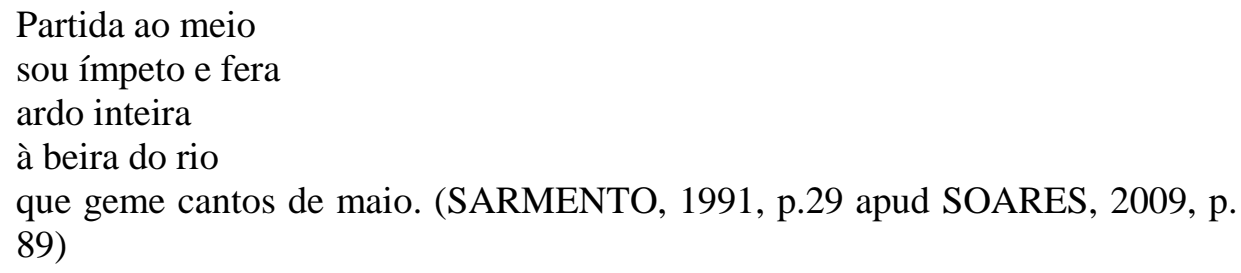

Esta é uma representação clara na qual a mulher busca sua origem primitivaanimalesca: a "fera" que está dentro dela por meio do prazer alcançado com os estímulos eróticos, os quais não estão evidentes no texto, fazem com que ela ganhe traços bestiais. A mulher deixa de ser apenas o ser submisso o qual deveria dar prazer ao seu parceiro, sem se importar com o próprio, tornando-se assim, aquela que consegue o prazer individualmente.

Logo, a natureza erotizada gera teor poético nos textos apresentados anteriormente, tornando visível que a natureza pode ir além de ser um escape da vida urbana, formando-se assim em um signo do erótico. Pela relação entre a natureza e o erótico, façamos agora uma análise intersemiótica entre a poesia de Bacellar e as fotografias de Litaiff. 


\title{
NATUREZA: LIRISMO E SIGNOS DO ERÓTICO
}

A natureza é um tema muito presente na obra do escritor amazonense Luiz Bacellar (1928-2012). Em Sol de feira (2008), por exemplo, há vários poemas que exploram as frutas da região amazônica de um ponto de vista erótico. Isso nos remete ao que Santaella afirma sobre signo

O homem só conhece o mundo porque, de alguma forma, o representa e só interpreta essa representação numa outra representação, que Peirce denomina interpretante da primeira. Daí que o signo seja uma coisa de cujo conhecimento depende do signo, isto é, aquilo que é representado pelo signo (2012, p. 80)

Portanto, o signo, enquanto fluido e inacabado, não se fecha em um sentido completo: é imensamente plural, é aquilo que se desloca e se esquiva incessantemente. É o que Bacellar faz ao resignificar as frutas amazônicas, atribuindo-lhes uma conotação erótica, ou, nas palavras de Nunes, criando "jogos frutais" (2008 apud MELO NETO, 2008, p. 11).

Da mesma maneira age o fotógrafo coariense Normady Litaiff, na série de sua autoria, intitulada "Amazônia Erótica", que está publicada no livro As artes plásticas no Amazonas -o clube da madrugada (2011). Na série fotográfica, o artista lança um olhar diferenciado para a natureza, criando novos signos a partir dos signos que ela produz: os troncos, galhos de árvores não são apenas signos do meio ambiente, mas também (e, sobretudo) signos do erótico.

Retomemos o que Bataille nos fala sobre erotismo "O objeto do desejo é diferente do erotismo. Não é todo o erotismo, mas é atravessado por ele" (1985, p. 87). Ou seja, a natureza é transpassada, não fica intacta nem inerte, começa a se tornar agente do erótico na visão do fotógrafo. Em sua ótica, a natureza acaba por ganhar um sentido de conotação sensual, passando de agente passivo do meio ambiente, para poder transformar-se em agente ativo do erótico humano.

Partindo dessas concepções, podemos analisar no poema "Rondel do cupuaçu":

\author{
cupuaçu \\ és soberano \\ do pomulário \\ americano \\ num cofre pardo \\ guardas com ciúmes \\ raros sabores \\ vivos perfumes
}




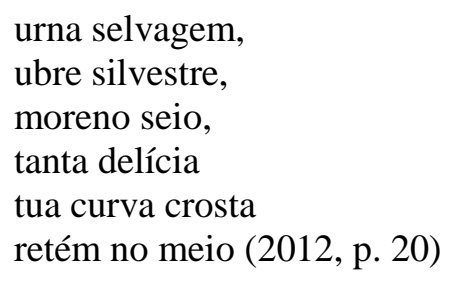

O eu lírico resignifica o cupuaçu e o associa à mulher: "moreno seio/tanta delícia/tua curva crosta/retém no meio". Para aqueles que já provaram o Theobroma grandiflorum sabem do sabor muito característico do fruto, o qual o eu lírico enaltece, comparando-o ao sabor do púbis feminino. Processo semelhante é possível observar na fotografia (figura 1) de Normandy Litaiff:

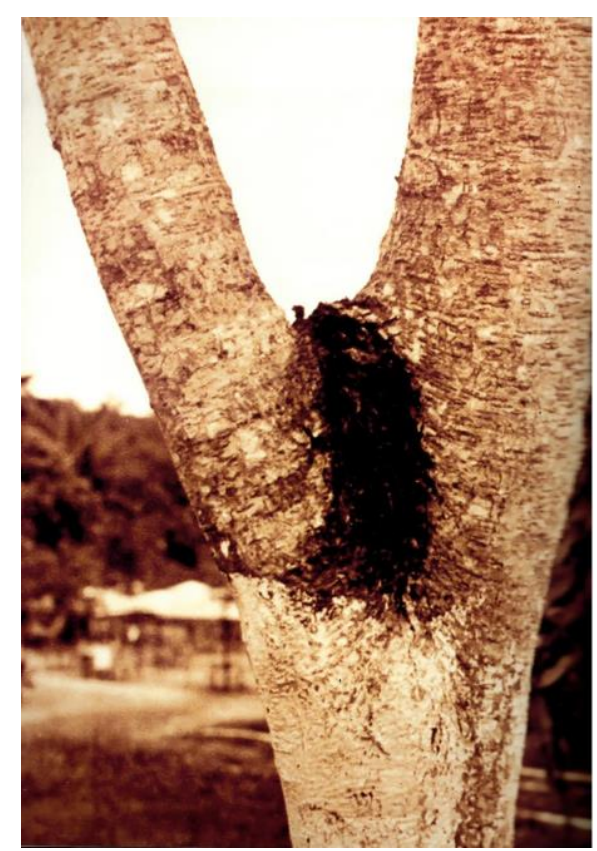

Figura 1 - Série Amazônia Erótica I Fonte: LITAIFF, 2011, p. 232

Para Santaella, "fotografar é (...) um ato de escolha, fruto de uma atenção seletiva" (2012, p.76). Litaiff usa da sensibilidade fotográfica para relacionar o tronco da árvore à genitália feminina. Processo semelhante ao que produz Bacellar ao relacionar o cupuaçu com o corpo extremamente erótico da mulher, formando assim, uma sinergia entre a obra dos dois autores.

Há ainda outro poema de Bacellar em que os signos da natureza são resignificados, ganhando conotações eróticas. Trata-se de "Rondel do bacuri", a partir do qual traçaremos 
comparações com outras duas fotografias de Litaiff, uma vez que ambos convergem entre o ato sexual de um homem com uma mulher até o, enfim desejado, êxtase. Comecemos pelo texto de Bacellar.

\author{
Gemas da mata \\ de galas flácidas \\ pérolas ácidas \\ bagas de prata \\ tens bacuri \\ áspero e louro \\ pômulo de ouro \\ dentro de ti \\ tuas polpas belas \\ abrem-se e escorrem \\ seivas sutis \\ como as estrelas \\ sorrindo morrem \\ chorando ris. (BACELLAR, 2012, p. 17)
}

O eu lírico associa as cores do fruto amazônico a gemas, que por sua vez são associadas ao testículo. Nos versos seguintes, observamos trechos que representam tanto o aparelho reprodutor masculino - "de galas flácidas/pérolas ácidas/bagas de prata" -, como o feminino "pômulos de ouro/dentro de ti", que podem ser lidos como representação do ovário feminino. O fruto representa assim, tanto o testículo detentor do sêmen, quanto o ovário feminino, receptor natural. O êxtase é representado na segunda estrofe - "tuas polpas belas/abrem-se e escorrem/seivas sutis" -, quando acontece o deleite do casal, o qual, após o ato, chega a seu ápice. Após o término, os dois corpos separam-se do ato e estão em plenitude pós-sexual: "como as estrelas/sorrindo morrem/chorando ris".

Retomemos as acepções que Octavio Paz (1994) faz sobre sexualidade e erotismo:

Uma vez delimitadas, de forma sumária e tosca, as fronteiras da sexualidade, podemos traçar uma linha divisória entre esta e o erotismo. Uma linha sinuosa e não poucas vezes violada, seja pela erupção violenta do instinto sexual seja pelas incursões da fantasia erótica. Antes de tudo, o erotismo é exclusivamente humano; é sexualidade socializada e transfigurada pela imaginação e vontade dos homens. A primeira coisa que diferencia o erotismo da sexualidade é a infinita variedade de formas em que se manifesta, em todas as épocas e em todas as terras. O erotismo é invenção, variação incessante; o sexo é sempre o mesmo. O protagonista do ato erótico é o sexo ou, mais exatamente, os sexos. O plural é obrigatório porque, incluindo os chamados prazeres solitários, o 
desejo sexual inventa sempre um parceiro imaginário... ou muitos. Em todo encontro erótico há um personagem invisível e sempre ativo: a imaginação, o desejo. No ato erótico intervêm sempre dois ou mais, nunca um. Aqui aparece a primeira diferença entre a sexualidade animal e o erotismo humano: neste, um ou mais participantes podem ser um ente imaginário. Só os homens e as mulheres copulam com íncubos e súcubos (1994, p.16).

Para ele, o ato sexual feito é o mesmo, não importando com quem seja, o que diferencia da pessoa para outra é o erotismo, pois cada um desenvolve uma visão imaginária do outro, que pode ser alcançada ou não. O sexo, de certa forma, é mecânico, unilateral; já o erotismo, é abrangente e pulsante, não possui começo, meio ou fim. Assim, signos comuns pujantes no subconsciente humano podem adquirir novos significados erotizados.

Passemos, então às fotografias de Litaiff e à análise dos signos estéticos e eróticos que as compõem.

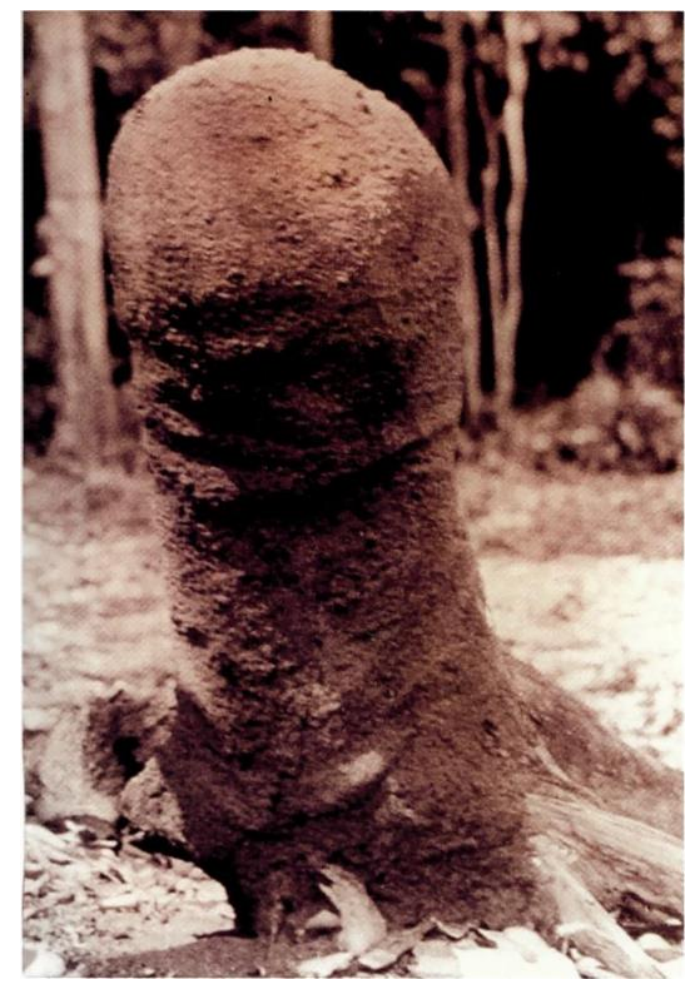

Figura 2 - Série Amazônia Erótica $V$ Fonte: LITAIFF, 2011, p. 237

$\mathrm{Na}$ figura 2 da "Série Amazônica Erótica V", Litaiff eterniza a imagem de uma (possível) colmeia de aparência similar ao órgão sexual masculino (o pênis ereto com a glande exposta), representando assim um vislumbre do erotismo na natureza. Se retomarmos o pensamento de Santaella, veremos que: 
Fotos realizam com primor o cruzamento mais que perfeito entre tempo e espaço. Toda foto, qualquer foto que seja, congela e eterniza o tempo. Toda foto, qualquer foto que seja, congela e eterniza o tempo. Clicar o botão significa cortar, sem revogação possível, o fluxo do tempo e, consequentemente, o escorrer da vida. O que ficou lá capturado interrompeu o continuum da existência dos seres e das coisas. Mas ganhou, com isso, a eternidade e a possibilidade de ser reproduzido em infinitas cópias (2012, p. $80)$.

Ora, Litaiff com visão aguçada e perspicaz, num indício de um olhar diferenciado para a natureza, lascivou-o, fotografando uma colmeia em formato fálico, criando um signo icônico a partir de um objeto inanimado e perpetuando o novo signo em imagem.

Já na figura 3 da Série Amazônia Erótica IV, que aparece a seguir, podemos observar a criação de um signo icônico que nos leva e associar o objeto da natureza morta ao órgão sexual feminino.

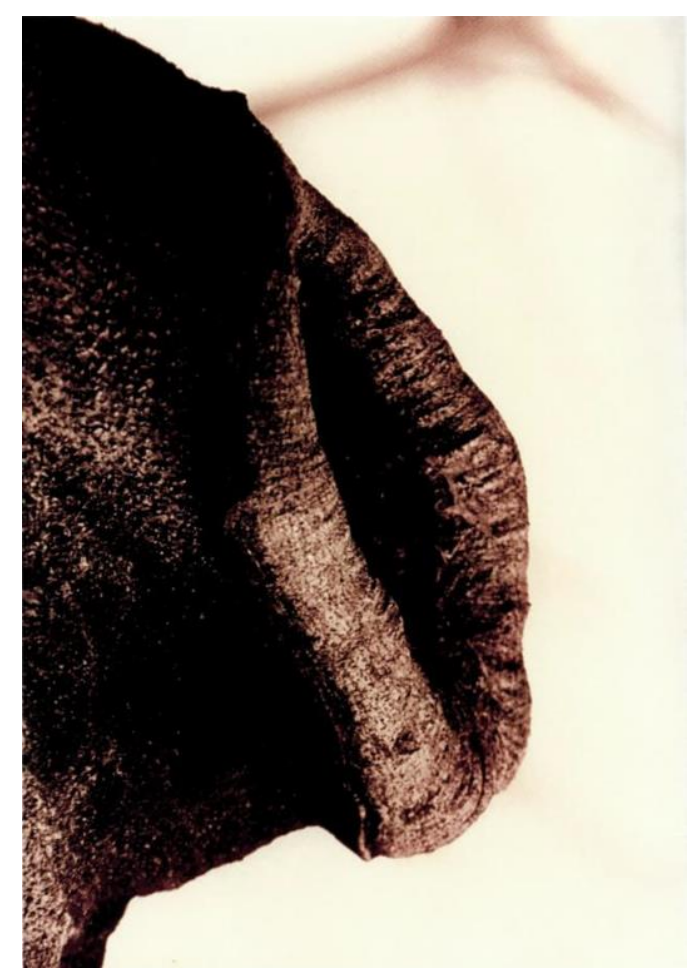

Figura 3 - Série Amazônia Erótica IV

Fonte: LITAIFF, 2011, p. 236

O tronco da árvore é capturado a partir de um novo olhar que o fotógrafo lança. Semelhante à vulva, o que era signo da flora ganha uma conotação sexual. A percepção que o fotógrafo nos remete a assertiva de Santaella de que quanto "mais uma foto for portadora de 
valores simbólicos, mais carregada ela estará de significados coletivos que falam à cultura". (2012, p. 81), ou seja, amplia-se o signo antes estagnado como parte da natureza, tornando-o representação de objeto de desejo sexual.

Retomando os textos de Bacellar que ganharam teor erótico e as fotos erotizada de Litaiff, chegamos ao pensamento de Paz:

Submetidos à perene descarga elétrica do sexo, os homens inventaram o páraraios: o erotismo. Invenção equívoca, como todas as que idealizamos: o erotismo propicia a vida e a morte. Começa a se desenhar agora com maior precisão a ambiguidade do erotismo: é repressão e permissão, sublimação e perversão. (...) $\mathrm{O}$ erotismo defende a sociedade dos assaltos da sexualidade, mas também nega a função reprodutiva. É o caprichoso servidor da vida e da morte (1994, p. 18)

Como podemos perceber, o sexo é uma das principais formas de prazer que pode ser alcançado por duas pessoas quando em sinergia, porém, ele é somente um dos meios possíveis de prazer do ser humano, com uma única via. Já o erotismo é abrangente: pode-se gerar uma satisfação através do imaginário, sem que haja o contato físico.

Após analisarmos as obras em tela, podemos concluir que o erotismo pode estar presente em quaisquer signos existentes, precisando apenas da imaginação lasciva para gerar um novo signo erótico para o signo já dotado de teor semântico. Assim, tantos nos poemas de Bacellar como nas fotografias de Litaiff, existe uma coesão entre a poesia erotizada, mostrando a natureza de forma diferente - não aquela que seja estática e romântica de Machado, mas aquela que ganha vida e, além disso, passa a ter um novo campo icônico: a natureza projetando libido. A fotografia sendo detentora de um olhar atento, a qual eterniza o momento (SANTAELLA, 2012, p. 81), pode possuir um novo olhar para o novo campo icônico, mostrando assim, a importância da imagem para poder retratar um instante e fazendo com que ocorra um novo signo à natureza. Tratando-se de sexo, amor e erotismo, percebeu-se que apesar da tríade estar intrinsicamente correlacionada, as partes são distintas entre si e é através do erotismo que podemos alcançar os outros dois: o sexo e o amor.

Apesar de Bacellar e Litaiff trabalharem com estéticas distintas, é possível notar aproximação temática em suas obras. Comparando a poesia e a fotografia dos dois autores, percebemos como as duas obras, apesar de serem de áreas diferentes, mostram-se numa relação intersemiótica, convergindo. Quando estudamos o texto, com todo o teor poético, percebemos a intertextualidade com a fotografia, tendo em vista que a imagem mostra de forma ampla, a visão 
a qual o poeta imaginou no momento em que estava escrevendo sobre a natureza em sua representação alterada. Logo, Bacellar e Litaiff, criaram campos semelhantes de representações icônicas da natureza, acerca do signo erótico, assim as frutas e a natureza que passavam desapercebidos, ganharam novas representações eróticas.

\section{Referências}

BACELLAR, Luiz. Sol de feira. 7. a edição. - Manaus: Editora Valer, 2008.

BATAILLE, Georges. O erotismo. Tradução de Antonio Carlos Viana. - Porto Alegre: L\&PM, 1987.

BEÇA, Aníbal. Águas de Manaus. - Manaus: Editora Muhraida, 2006.

BRAGA, Celdo. Varal: Sonhos ao sol. - Manaus: Editora Valer, 2010.

CAMINHA, P. Vaz de. A carta de Pero Vaz de Caminha: reprodução fac-similar do manuscrito com leitura justalinear, de Antônio Geraldo da Cunha, César Nardelli Cambraia e Heitor Megale. São Paulo: Humanitas, 1999.

DE ASSIS, Machado. Obra completa. - Rio de Janeiro: Nova Aguilar, 1994.

KOSSOY, Boris. Fotografia e História. São Paulo: Ática, 1989. (Série Princípios).

PÁSCOA, Luciane Viana Barros. As artes plásticas no Amazonas - o Clube da Madrugada. Manaus: Editora Valer, 2011.

PAZ, Octavio. A dupla chama. Tradução de Wladir Drupont. - São Paulo: Sciliano, 1994. . Os Filhos do barro: do romantismo à vanguarda. Tradução de Olga Savary. -

Rio de Janeiro: Nova Fronteira, 1984.

SANTAELLA, Lucia. Leitura de imagens. São Paulo: Editora Melhoramentos, 2012.

SCHWARTZ, Auturo. Man Ray - the rigour of imagination. New York: Rizzoli, 1977.

SOARES, Angélica. Por uma recriação ecológica do erotismo: flashes da poesia brasileira e portuguesa contemporâneas de autoria feminina. IN: Ipotesi, revista de estudos literários Juiz de Fora, v. 5, n. 2. p. 81 a 97, 2009.

SUASSUNA, Ariano. Iniciação à Estética. Recife: Universitária, 1975.

Recebido em: 01/02/2018

Aprovado em: 03/03/2018

Publicado em: 01/07/2018 